\title{
Trace elements in bone of Zalophus californianus from the Gulf of California: A comparative assessment of potentially polluted areas
}

\section{Elementos traza en hueso de Zalophus californianus en el golfo de California: Una evaluación comparativa de áreas potencialmente contaminadas}

\author{
Diana Szteren $^{1 *}$, David Aurioles-Gamboa ${ }^{2}$ \\ ${ }^{1}$ Departamento de Ecología y Evolución, Facultad de Ciencias, Universidad de la República, Iguá 4225, \\ Montevideo 11400, Uruguay. \\ ${ }^{2}$ Laboratorio de Ecología de Pinípedos “Burney J Le Boeuf”, Centro Interdisciplinario de Ciencias Marinas, \\ Instituto Politécnico Nacional, Av. Instituto Politécnico Nacional s/n, Col. Playa Palo de Santa Rita, La Paz, \\ 23096, Baja California Sur, México. \\ * Corresponding author. E-mail: diana@fcien.edu.uy
}

\begin{abstract}
As a top predator, California sea lions (Zalophus californianus) can be used as sentinels to record ecosystem conditions because of the trace metals that bioaccumulate in their tissues and are biomagnified in the trophic webs. The concentration of 11 trace elements (Al, As, $\mathrm{Cd}, \mathrm{Co}, \mathrm{Cu}, \mathrm{Fe}, \mathrm{Hg}, \mathrm{Ni}, \mathrm{Pb}, \mathrm{Se}$, and $\mathrm{Zn}$ ) was measured in California sea lion skulls from four regions of the Gulf of California (Mexico): Northern Gulf, Ángel de la Guarda, Central Gulf, and Southern Gulf. The aims of this study were (1) to determine and compare the mean concentration of trace elements among the four regions, and (2) to estimate the pollution situation of each region using the more toxic trace elements. The elements found in higher concentration in sea lion bone were $\mathrm{Al}$ (overall mean of $\left.73.70 \mu \mathrm{g} \mathrm{g}^{-1}\right)$ and $\mathrm{Zn}\left(60.78 \mu \mathrm{g} \mathrm{g} \mathrm{g}^{-1}\right)$. Only the concentration of As and $\mathrm{Hg}$ showed significant differences among regions: As was higher in the Central Gulf than in Ángel de la Guarda and the Northern Gulf, while Hg was higher in the Northern Gulf and Ángel de la Guarda than in the Central and Southern Gulf. The comparative analysis of the pollution situation indicated that the Central Gulf was the most affected by As and Cd, and the Northern Gulf and Ángel de la Guarda by Hg. Regions with different trace element concentrations may reflect different feeding habits and oceanographic conditions, and are congruent with other regional patterns suggested for the Gulf of California.
\end{abstract}

Key words: California sea lion, trace elements, bone, geographic pattern, Gulf of California.

RESUMEN. Como depredador tope, el lobo marino de California (Zalophus californianus) puede ser utilizado como especie centinela para registrar condiciones ecosistémicas por los elementos traza que bioacumula y que son biomagnificados en las redes tróficas. Se midió la concentración de 11 elementos traza ( $\mathrm{Al}, \mathrm{As}, \mathrm{Cd}, \mathrm{Co}, \mathrm{Cu}, \mathrm{Fe}, \mathrm{Hg}, \mathrm{Ni}, \mathrm{Pb}, \mathrm{Se}$ y $\mathrm{Zn}$ ) en los cráneos de lobo marino de California de cuatro regiones del golfo de California: Golfo Norte, Ángel de la Guarda, Golfo Central y Golfo Sur. Los objetivos del estudio fueron (1) determinar y comparar la concentración de elementos traza entre las cuatro regiones, y (2) estimar el estado de polución de cada región usando los elementos traza más tóxicos. Los elementos encontrados en mayor concentración en hueso de lobo marino fueron $\mathrm{Al}$ (media global: $73.70 \mu \mathrm{g} \mathrm{g}^{-1}$ ) y $\mathrm{Zn}$ $\left(60.78 \mu \mathrm{g} \mathrm{g}^{-1}\right)$. Sólo las concentraciones de As y $\mathrm{Hg}$ mostraron diferencias significativas entre regiones. El As fue más alto en la región Golfo Central que en Ángel de la Guarda y en Golfo Norte, mientras que el Hg fue más alto en la región Golfo Norte y Ángel de la Guarda que en Golfo Central y Golfo Sur. El análisis comparativo del estado de polución en cada región indicó que la región Golfo Central fue la más afectada por As y Cd, y las regiones Golfo Norte y Ángel de la Guarda por Hg. Las regiones con diferentes concentraciones de elementos traza podrían reflejar diferencias en los hábitos alimentarios y condiciones oceanográficas, y son congruentes con otros patrones regionales sugeridos para el golfo de California.

Palabras clave: lobo marino de California, elementos traza, hueso, patrón geográfico, golfo de California.

\section{INTRODUCTION}

As top predators and due to their longevity, sea lions are appropriate species for recording ecosystem conditions as biomonitors of certain environmental conditions such as pollution, presence of particular prey species, and productivity (Aurioles-Gamboa and Zavala-González 1994, Fair and Becker 2000). Furthermore, they enable monitoring trace elements that biomagnify in the trophic webs (Ikemoto et al.

\section{INTRODUCCIÓN}

Los lobos marinos son especies apropiadas para registrar condiciones del ecosistema ya que son depredadores tope, longevos y biomonitores de características ambientales como la polución, la presencia de especies presa en particular y la productividad (Aurioles-Gamboa y Zavala-González 1994, Fair y Becker 2000). También permiten el monitoreo de elementos traza que se biomagnifican en las redes tróficas 
2004). Sea lions require considerable amounts of food to support their high metabolism, which makes them useful sentinels to detect environmental concentrations of heavy metals (Sydeman and Jarman 1998, Elorriaga-Verplancken and Aurioles-Gamboa 2008).

Living organisms take trace elements through water, by ingestion through food (e.g., $\mathrm{Cd}, \mathrm{Cu}, \mathrm{Zn}$ ), by absorption through skin lesions $(\mathrm{Hg})$ or by breathing, depending on the element and its chemical status (Skoch 1990). Although some trace elements are essential and have an important role in metabolism since they are required in low concentrations (e.g., $\mathrm{Co}, \mathrm{Cu}, \mathrm{Fe}, \mathrm{Se}, \mathrm{Zn}$ ), they may become toxic when exceeding a certain threshold (Baraj et al. 2009). Conversely, highly toxic trace elements (e.g., $\mathrm{As}, \mathrm{Cd}, \mathrm{Pb}, \mathrm{Hg}$ ) are very dangerous even at low concentrations, and may cause multiple symptomatic effects. They do not have any biological function and besides occurring naturally, they may reflect an environment polluted by anthropogenic activities (Thompson 1990).

The amounts of As, accumulated from saltwater and prey items, tend to be higher in high-trophic-level animals (Eisler 1988). Its concentration in marine organisms is much higher than in terrestrial organisms (Lunde 1977). In high concentrations, As may produce gastrointestinal, neurological, circulatory, and excretory problems (Skoch 1990). Cd is related to circulatory and excretory deficiencies. The main effects of $\mathrm{Cd}$ exposure are kidney damage, disturbances of $\mathrm{Ca}$ and vitamin D metabolism, and bone loss. Species that feed on cephalopods and crustaceans show a higher trend to accumulate high levels of $\mathrm{Cd}$, which is naturally present in these invertebrates regardless of their exposure to anthropogenic contamination (Reijnders 1993, Gerpe et al. 2000). Hg is absorbed and accumulated as methylmercury, its organic form, which is soluble in lipids and primarily targets the nervous system (Wren et al. 1995). This element usually biomagnifies through the trophic web and also increases its concentration with age (Eisler 1987). Pb may be important for carnivorous marine mammals as it accumulates in higher concentrations in hard tissues, such as bone and teeth, and lower concentrations in soft tissues (Braham 1973, Thompson 1990).

During development, calcified tissues incorporate trace elements to which they are exposed through intercellular matrix calcification (Gdula-Argasinska et al. 2004). Bone tissue has some advantages compared to soft tissues, such as liver and kidney, because the reasonably long life of newlysynthesized bone in all but the youngest individuals allows this tissue to act as a sink for a wide variety of substances (Triffit 1985). Compact bones have low turnover rates; hence, the analysis of these elements may reflect the accumulation during many years of the animal's life. Consequently, bone tissue serves as an accurate historic record of exposure to various elements, being a suitable long-term bioindicator of environmental exposure (Gdula-Argasinska et al. 2004). Some anthropogenic toxic trace elements may cause death
(Ikemoto et al. 2004). Los lobos marinos requieren de cantidades considerables de alimento para mantener su alto metabolismo, lo que los hace útiles centinelas para detectar la concentración ambiental de metales pesados (Sydeman y Jarman 1998; Elorriaga-Verplancken y Aurioles-Gamboa 2008).

Los organismos vivos obtienen elementos traza a través del agua, por su ingesta a través del alimento (e.g., $\mathrm{Cd}, \mathrm{Cu}$, $\mathrm{Zn})$, por la absorción vía lesiones en la piel $(\mathrm{Hg})$ o por la respiración, dependiendo del elemento y de su estatus químico (Skoch 1990). A pesar de que algunos elementos traza son esenciales y tienen un papel importante en el metabolismo, ya que se requieren en concentraciones bajas (e.g., $\mathrm{Co}, \mathrm{Cu}$, $\mathrm{Fe}, \mathrm{Se}, \mathrm{Zn}$ ), se pueden convertir en tóxicos cuando exceden cierto umbral (Baraj et al. 2009). Por otro lado, los elementos traza altamente tóxicos (e.g., $\mathrm{As}, \mathrm{Cd}, \mathrm{Pb}, \mathrm{Hg}$ ) son muy peligrosos incluso a concentraciones bajas, pudiendo causar múltiples efectos sintomáticos. No desempeñan ninguna función biológica $\mathrm{y}$, además de ocurrir naturalmente, pueden reflejar un ecosistema poluto por actividades antropogénicas (Thompson 1990).

Las cantidades de As, acumuladas por el agua marina y el consumo de presas, tienden a ser mayores en animales de alto nivel trófico (Eisler 1988). Su concentración en los organismos marinos es mucho mayor que en los organismos terrestres (Lunde 1977). En altas concentraciones, el As puede producir problemas gastrointestinales, neurológicos, circulatorios y excretorios (Skoch 1990). El Cd está relacionado con deficiencias circulatorias y excretoras. Los efectos principales de la exposición ante $\mathrm{Cd}$ son daño en los riñones, disturbios en el metabolismo del Ca y de la vitamina $\mathrm{D}, \mathrm{y}$ pérdida de hueso. Las especies que se alimentan de cefalópodos y crustáceos muestran una mayor tendencia a acumular altos niveles de $\mathrm{Cd}$, que está presente en dichos invertebrados mas allá de su exposición a la contaminación antropogénica (Reijnders 1993, Gerpe et al. 2000). El Hg se absorbe y se acumula en su forma orgánica como metilmercurio, que es soluble en lípidos y cuyo principal blanco es el sistema nervioso (Wren et al. 1995). Este elemento usualmente aumenta su concentración con la edad y se biomagnifica a través de la red trófica (Eisler 1987). El Pb puede ser importante en mamíferos marinos carnívoros ya que se acumula en mayores concentraciones en tejidos duros, tales como hueso $\mathrm{y}$ dientes, $\mathrm{y}$ en menores concentraciones en tejidos blandos (Braham 1973, Thompson 1990).

Durante el desarrollo, los tejidos calcificados incorporan elementos traza a los que están expuestos a través de la calcificación de la matriz intercelular (Gdula-Argasinska et al. 2004). El tejido óseo presenta algunas ventajas en comparación con los tejidos blandos, tales como el hígado o el riñón, debido a que la larga vida del hueso recién sintetizado en todos excepto los individuos más jóvenes permite que éste tejido actúe como reservorio de una gran variedad de sustancias (Triffit 1985). Los huesos compactos tienen bajas tasas de renovación; por lo tanto, el análisis de estos elementos 
or induce it by affecting the immune system, increasing the chances of diseases (Geraci et al. 1999). Overall toxicity depends on the chemical form of the element, the organ affected, physiological status, age, size, gender, and reproductive status of the animals (Reijnders et al. 1993).

The California sea lion, Zalophus californianus, inhabits temperate and subtropical waters from British Columbia, SW Canada $\left(51^{\circ} \mathrm{N}\right)$, to the SW coast of Mexico $\left(19^{\circ} \mathrm{N}\right)$. This species is the most abundant pinniped in Mexico, with the broadest distribution, and is the only one inhabiting the Gulf of California permanently in 13 rookeries, accounting for a population ranging from 24,062 to 31,159 individuals (Szteren et al. 2006). The population in the Gulf of California has been recently grouped into four different regions according to ecological and biological parameters: Northern Gulf (three rookeries), Ángel de la Guarda (four rookeries), Central Gulf (four rookeries), and Southern Gulf (two rookeries) (Szteren and Aurioles-Gamboa 2011). One of the variables used to group rookeries into regions was the concentration of six trace elements $(\mathrm{Cu}, \mathrm{Fe}, \mathrm{Hg}, \mathrm{Se}, \mathrm{Pb}$, and $\mathrm{Zn})$ analyzed in hair samples from pups. The concentrations of these elements revealed a latitudinal pattern among eight rookeries, with significant variation between sites (Elorriaga-Verplancken and Aurioles-Gamboa 2008). Labrada-Martagón et al. (2007) analyzed concentration levels of $\mathrm{Ca}, \mathrm{P}, \mathrm{K}, \mathrm{Na}, \mathrm{Fe}, \mathrm{Mg}$, and $\mathrm{Zn}$ in California sea lion teeth from animals of both sexes and distinct ages in connection to the degree of tooth erosion. The study did not find significant relations but only a decreasing trend in $\mathrm{Ca}$ for females as they get older. These authors suggested that females may be more prone to decalcification due to the annual $\mathrm{Ca}$ investment in their offspring.

During lactation, mothers make foraging trips usually within a 50-km radius from the breeding site (Kuhn 2006). Furthermore, the variations in feeding habits among sea lions in the Gulf of California imply slight changes in their trophic level between rookeries, since the diet of their prey may vary from zooplankton to fish and squid (García-Rodríguez and Aurioles-Gamboa 2004, Aurioles-Gamboa et al. 2009). This, in turn, leads to the generation of characteristic feeding habits by each colony in a region (García-Rodríguez and AuriolesGamboa 2004, Porras-Peters et al. 2008). Consequently, the composition of the diet and trophic level may influence the levels of certain toxic elements found in the predators (Jarman et al. 1996).

Increased concentrations of heavy metals may predispose animals to suffer from health problems, but little is known about the presence and level of trace elements in California sea lions. In this study we examined the concentration of 11 trace elements ( $\mathrm{Al}, \mathrm{As}, \mathrm{Cd}, \mathrm{Co}, \mathrm{Cu}, \mathrm{Fe}, \mathrm{Hg}, \mathrm{Ni}, \mathrm{Pb}, \mathrm{Se}$, and $\mathrm{Zn}$ ) accumulated throughout the lifespan in the skull of individuals from the four previously defined regions for sea lion rookeries in the Gulf of California. In this context, the aims of this study were (1) to determine and compare the mean concentration of trace elements among the four regions, and (2) to estimate the pollution situation of sea lions puede reflejar su acumulación a lo largo de muchos años en la vida del animal. Como consecuencia, el tejido óseo sirve como un registro histórico preciso de la exposición ante varios elementos traza y sería un bioindicador de largo plazo apropiado (Gdula-Argasinska et al. 2004). Algunos elementos traza tóxicos podrían causar la muerte o inducirla afectando el sistema inmune, aumentando así la probabilidad de contraer enfermedades (Geraci et al. 1999). La toxicidad global depende de la forma química del elemento, del órgano afectado, del estatus fisiológico, de la edad, del tamaño, del sexo y del estatus reproductivo de los animales (Reijnders et al. 1993).

El lobo marino de California (Zalophus californianus) habita aguas templadas y subtropicales desde Columbia Británica, sudoeste de Canadá $\left(51^{\circ} \mathrm{N}\right)$, hasta la costa sudoeste de México $\left(19^{\circ} \mathrm{N}\right)$. Esta especie es el pinnípedo más abundante de México, con la distribución más amplia, y es el único que habita permanentemente en el golfo de California en 13 colonias reproductivas que cuentan con una población de 24,062 a 31,159 individuos (Szteren et al. 2006). La población del golfo de California ha sido agrupada en cuatro regiones diferentes con base en parámetros biológicos y ecológicos: Golfo Norte (tres colonias), Ángel de la Guarda (cuatro colonias), Golfo Central (cuatro colonias) y Golfo Sur (dos colonias) (Szteren y Aurioles-Gamboa 2011). Una de las variables usadas para agrupar las colonias en regiones fue la concentración de seis elementos traza $(\mathrm{Cu}, \mathrm{Fe}, \mathrm{Hg}, \mathrm{Se}$, $\mathrm{Pb}$ y $\mathrm{Zn}$ ) analizados en pelo de crías. La concentración de estos elementos reveló un patrón longitudinal a lo largo de ocho colonias, con variaciones significativas entre los sitios (Elorriaga-Verplancken y Aurioles-Gamboa 2008). LabradaMartagón et al. (2007) analizó los niveles de concentración de $\mathrm{Ca}, \mathrm{P}, \mathrm{K}, \mathrm{Na}, \mathrm{Fe}, \mathrm{Mg}$ y $\mathrm{Zn}$ en dientes de lobo marino de California de ambos sexos y diferentes edades, en conexión con el grado de erosión de los dientes. El estudio no encontró relaciones significativas, excepto una tendencia decreciente del Ca de las hembras con la edad. Los autores sugirieron que las hembras estarían más propensas a la descalcificación debido a su inversión de $\mathrm{Ca}$ anual para las crías.

Durante la lactancia, las madres realizan viajes de alimentación dentro de un radio menor que los $50 \mathrm{~km}$ alrededor de los sitios de críanza (Kuhn 2006). Por lo tanto, las variaciones en los hábitos alimentarios entre los lobos marinos en el golfo de California implican leves cambios en el nivel trófico entre las colonias, ya que la dieta de sus presas principales puede variar desde el zooplancton hasta peces o calamares (García-Rodríguez y Aurioles-Gamboa 2004, AuriolesGamboa et al. 2009). Esto lleva a la generación de hábitos alimentarios característicos de cada colonia en una región (García-Rodríguez y Aurioles-Gamboa 2004, Porras-Peters et al. 2008). Por consiguiente, la composición de la dieta y el nivel trófico pueden influenciar los niveles de ciertos elementos tóxicos que se encuentran en los depredadores (Jarman et al. 1996). 
in each region regarding the most toxic trace elements. Due to different feeding habits of sea lions in the different regions (Szteren and Aurioles-Gamboa 2011), the regions may be characterized by the different incidence of trace elements. This study represents the most complete report of trace elements in Z. californianus from the Gulf of California to date and may serve as a baseline for further studies related to pollutants in marine mammals in this area.

\section{MATERIALS AND METHODS}

\section{Data collection and analytical processing}

For this study we used a total of 66 skulls of California sea lions, collected between 1978 and 1994 at 10 rookeries located in four regions of the Gulf of California (defined in Szteren and Aurioles-Gamboa 2011): Northern Gulf (San Jorge and Isla Lobos rookeries), Ángel de la Guarda (Granito, Los Cantiles, and Los Machos rookeries), Central Gulf (San Esteban, San Pedro Mártir, and Nolasco rookeries), and Southern Gulf (Farallón de San Ignacio and Los Islotes rookeries) (fig. 1).

In the laboratory, between 2 and $3 \mathrm{~g}$ of tympanic bulla were extracted with a drill, and washed with distilled and ionized water to avoid any contamination. The concentrations of $\mathrm{Al}, \mathrm{As}, \mathrm{Cd}, \mathrm{Co}, \mathrm{Cu}, \mathrm{Fe}, \mathrm{Hg}, \mathrm{Ni}, \mathrm{Pb}, \mathrm{Se}$, and $\mathrm{Zn}$ were determined using an AAnalyst 100/300 atomic absorption spectrometer at the Toxicology Laboratory, Department of Nutrition, School of Veterinary Medicine and Zootechnology, National Autonomous University of Mexico. The extraction of each element was done through wet digestion. Samples were placed with $5 \mathrm{~mL}$ of ultra-pure nitric acid and two glass pearls, and were heated between 36 and 48 hours. Then, the samples were heated in a micro-digestor at the nitric acid boiling temperature, providing constant heating and avoiding $\mathrm{Hg}$ loss by evaporation. Samples were left to cool down, then $2 \mathrm{~mL}$ of concentrated perchloric acid were added and they were heated again to complete the digestion.

Trace elements were quantified by flame atomic absorption spectrophotometry (AAS, Perkin-Elmer 2380). Hg and Se were measured with the same equipment, using flameless cold-vapor and hot-vapor, respectively. Se was measured by the generation of hot volatile Se hydride vapors. The absorbance of each sample was estimated by generating the element's hydride, and this value was used to estimate the concentration. The final concentration was calculated considering the aliquot used in generating the hydride.

The analytical conditions for each metal were established according to the manufacturer's manual (Perkin-Elmer 1996). The quality of the analyses by AAS was evaluated using certified reference material for bone (NIST-1400, National Institute of Standards and Technology, USA), and homogenized fish (IAEA-407, International Atomic Energy Agency, Monaco). Values are reported in $\mu \mathrm{g} \mathrm{g}^{-1}$ dry weight.
El incremento de las concentraciones de metales pesados puede predisponer a los animales a sufrir problemas de salud, aunque se conoce poco acerca de la presencia y el nivel de los elementos traza en el lobo marino de California. En éste estudio examinamos la concentración de 11 elementos trazas ( $\mathrm{Al}$, $\mathrm{As}, \mathrm{Cd}, \mathrm{Co}, \mathrm{Cu}, \mathrm{Fe}, \mathrm{Hg}, \mathrm{Ni}, \mathrm{Pb}, \mathrm{Se}$ y $\mathrm{Zn}$ ) acumulados a lo largo de la vida en cráneos de individuos provenientes de las cuatro regiones ya definidas en el golfo de California. En este contexto, los objetivos de éste estudio fueron (1) determinar y comparar la concentración media de elementos traza entre las cuatro regiones, y (2) estimar el estado de polución del lobo marino en cada región considerando los elementos traza más tóxicos. Las diferentes regiones pueden caracterizarse por la diferente incidencia de los elementos traza, debido a diferencias en los hábitos alimentarios de los lobos marinos entre las mismas (Szteren y Aurioles-Gamboa 2011). Este estudio representa el registro más completo de elementos traza en Zalophus californianus del golfo de California a la fecha, y puede servir como línea de base para futuros estudios relacionados con la polución en mamíferos marinos en esta área.

\section{MATERIALES Y MÉTODOS}

\section{Recolecta de datos y procedimientos analíticos}

Para este estudio, se utilizó un total de 66 cráneos de lobo marino de California recolectados entre 1978 y 1994 de 10 colonias reproductivas de cuatro regiones en el golfo de California (definidas en Szteren y Aurioles-Gamboa 2011): Golfo Norte (colonias San Jorge e Isla Lobos), Ángel de la Guarda (colonias Granito, Los Cantiles y Los Machos), Golfo Central (colonias San Esteban, San Pedro Mártir y Nolasco) y Golfo Sur (colonias Farallón de San Ignacio y Los Islotes) (fig. 1).

En el laboratorio, se extrajeron entre 2 y $3 \mathrm{~g}$ de bula timpánica con un taladro, y luego se lavaron con agua destilada e ionizada para evitar cualquier contaminación. Se determinó la concentración de $\mathrm{Al}, \mathrm{As}, \mathrm{Cd}, \mathrm{Co}, \mathrm{Cu}, \mathrm{Fe}, \mathrm{Hg}, \mathrm{Ni}, \mathrm{Pb}$, Se y $\mathrm{Zn}$ usando un espectrómetro de absorbancia atómica AAnalyst 100/300 en el Laboratorio de Toxicología, Departamento de Nutrición de la Facultad de Medicina Veterinaria y Zootecnia, Universidad Nacional Autónoma de México. La extracción de cada elemento fue realizada por digestión húmeda. Las muestras fueron colocadas en $5 \mathrm{~mL}$ de ácido nítrico ultra puro y dos perlas de vidrio, y fueron calentadas entre 36 y $48 \mathrm{~h}$. Luego, se calentaron las muestras en un micro digestor en el ácido nítrico a temperatura de hervor, en constante calentamiento y evitando la pérdida de $\mathrm{Hg}$ por evaporación. Una vez que se enfriaron las muestras, se les adicionaron $2 \mathrm{~mL}$ de ácido perclórico y fueron calentadas nuevamente para completar la digestión.

Los elementos traza fueron cuantificados con un espectrofotómetro de absorción atómica (AAS, por sus siglas en inglés; Perkin-Elmer 2380) por llama. El Se y Hg se midieron 


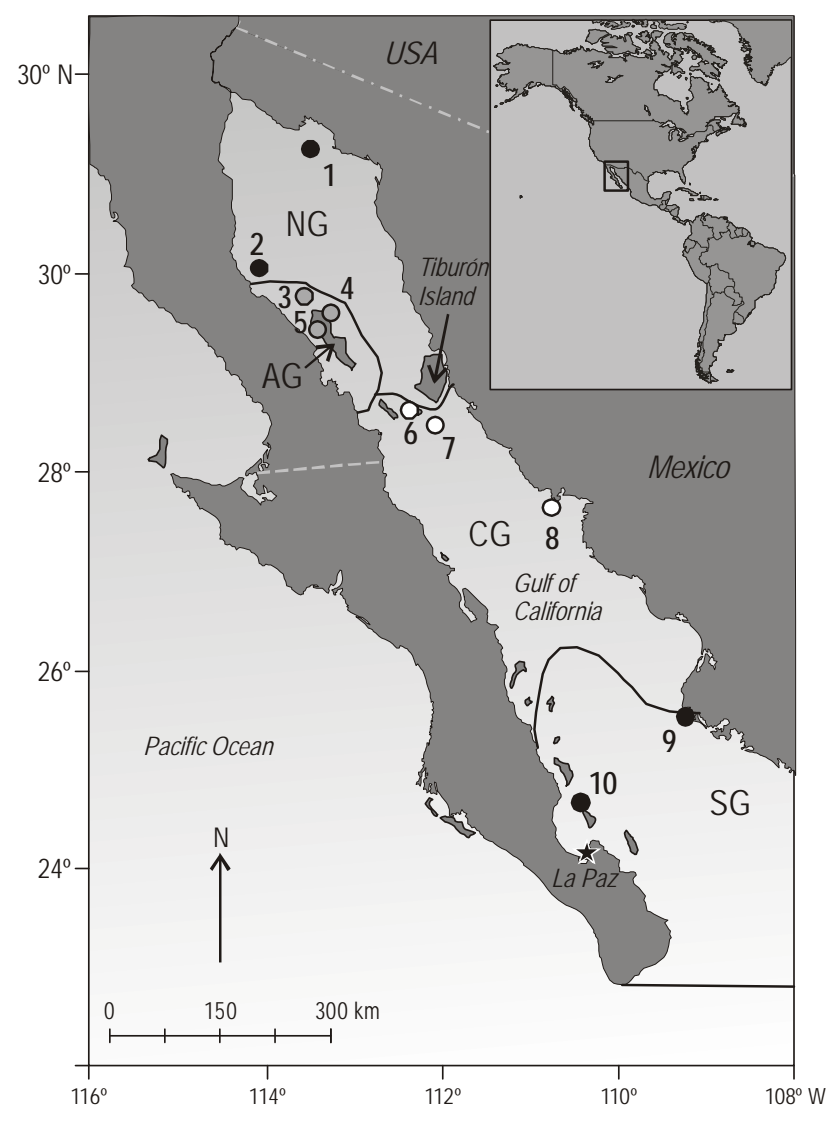

Figure 1. General regionalization of the California sea lion rookeries sampled in the Gulf of California (numbered circles with color pattern) and limits of the four environmental regions of the gulf as proposed by Lluch-Cota and Arias-Aréchiga (2000) (from Szteren and Aurioles-Gamboa 2011). NG, Northern Gulf group (1, San Jorge; 2, Isla Lobos); AG, Ángel de la Guarda group (3, Granito; 4, Los Cantiles; 5, Los Machos); CG, Central Gulf group (6, San Esteban; 7, San Pedro Mártir; 8, Nolasco); SG, Southern Gulf group (9, Farallón de San Ignacio; 10, Los Islotes).

Figura 1. Regionalización general de las colonias de lobo marino de California muestreadas en el golfo de California (círculos numerados con patrones de color) y límites de las cuatro regiones ambientales en el golfo propuestas por Lluch-Cota y AriasAréchiga (2000) (de Szteren y Aurioles-Gamboa 2011). NG, grupo Golfo Norte (1, San Jorge; 2, Isla Lobos); AG, grupo Ángel de la Guarda (3, Granito; 4, Los Cantiles; 5, Los Machos); CG, grupo Golfo Central (6, San Esteban; 7, San Pedro Mártir; 8, Nolasco); SG, grupo Golfo Sur (9, Farallón de San Ignacio; 10, Los Islotes).

Standards were obtained commercially or were elaborated from pure metallic salts of known concentration, to obtain a linear reading of absorbance. Absorbances were calibrated by the linear regression line for three standard solutions of known concentration for each element, distributed between the minimum and the maximum sensitivity limit to be determined, and a target solution as reference pattern of the reading range. The initial concentration was obtained by adding the slope value and the intersect, and then con el mismo equipo, usando vapor frío y caliente sin llama, respectivamente. El Se midió por la generación de vapores calientes volátiles de hidruro de Se. La absorbancia de cada muestra se estimó por la generación del hidruro de cada elemento, y éste valor fue usado para estimar la concentración. La concentración final se calculó considerando la alícuota utilizada en la generación del hidruro.

Las condiciones analíticas para cada metal fueron establecidas de acuerdo con el manual del fabricante (Perkin-Elmer 1996). Se evaluó la calidad de los análisis del AAS usando material de referencia certificado para hueso (NIST-1400, National Institute of Standards and Technology, EE UU), y pescado homogeneizado (IAEA-407, International Atomic Energy Agency, Monaco). Los valores se documentaron en $\mu \mathrm{g} \mathrm{\textrm {g } ^ { - 1 }}$ de peso seco.

Los estándares se obtuvieron comercialmente o se elaboraron a partir de sales metálicas de concentración conocida, para obtener una lectura lineal de absorbancia. Las absorbancias se calibraron a través de regresiones lineales de tres soluciones estándar de concentración conocida para cada elemento, distribuidas entre el límite mínimo y el máximo de sensibilidad a determinar, y una solución blanco como patrón de referencia del intervalo de lectura. La concentración inicial fue obtenida sumando el valor de la pendiente y el intercepto, y luego multiplicándolo por la absorbancia de cada muestra; de ésta manera se determinó la concentración de un elemento en cada mililitro de muestra. Las lecturas se realizaron dos veces para cada elemento traza, y se realizó una prueba de $t$ a las series de datos para determinar si las lecturas eran estadísticamente diferentes. De no hallarse diferencias, se usó el segundo valor.

\section{Análisis de datos}

Debido al bajo número de muestra de cráneos para algunas colonias, se juntaron los datos de las cuatro regiones. Para procesar esta base de datos, se descartaron los datos de crías y juveniles (hembras menores de 3 años y machos menores de 5 años) para reducir la variabilidad de los estadios no adultos porque no han establecido su estrategia de forrajeo ni desarrollado sus habilidades de buceo. Los datos pertenecieron a machos, excepto en el caso de una hembra en San Esteban, dos en Nolasco, dos en Farallón de San Ignacio y una en Los Islotes. Para comparar la concentración de los diferentes elementos traza entre regiones, se utilizaron pruebas de Kruskal Wallis, seguidas por pruebas U de MannWhitney como análisis a posteriori para comparar entre cada par de regiones. Adicionalmente, para rastrear las fuentes potenciales, se compararon especies de peces registradas en la dieta de los lobos marinos (Porras-Peters et al. 2008) con especies de peces incluidas en estudios de contenido de elementos traza, desarrollados en la costa de Sinaloa en el mismo periodo de tiempo (Ruelas-Inzunza et al. 2008, 2010).

Finalmente, para evaluar la susceptibilidad de los lobos marinos a sufrir problemas de salud relacionados con 
multiplying it by the absorbance of each sample; in this way we determined the concentration of an element in each milliliter of sample. Readings were made twice for each trace metal and a $t$-test was performed for series of data to determine if readings were statistically different. If no significant differences were found, then the second value was used.

\section{Data analysis}

Due to the small sample size of skulls from some rookeries, data were pooled for each one of the four ecological regions. To process this database, we discarded data from pups and juveniles (females less than 3 years old and males less than 5 years old) in order to reduce the variability of nonadult stages because they have not yet established their foraging strategy nor developed their diving skills. Data belonged to males, except in the case of one female from San Esteban, two from Nolasco, two from Farallón de San Ignacio, and one from Los Islotes. Kruskal-Wallis tests were used to compare the concentration of different trace elements among regions, followed by Mann-Whitney $U$-tests between each pair of regions as a post hoc analysis. Additionally, in order to track potential sources, we compared fish species recorded in the sea lion diet (Porras-Peters et al. 2008) and fish species included in studies on trace elements developed along the coast of Sinaloa in the same period (Ruelas-Inzunza et al. 2008, 2010).

Finally, to assess the susceptibility of sea lions to traceelement-related health problems, we selected the four highly toxic trace elements: $\mathrm{As}, \mathrm{Cd}, \mathrm{Hg}$, and $\mathrm{Pb}$. Since no data on the threshold level for Z. californianus or other Otariid species are available, we compared sea lion rookeries by regions. This comparison was carried out by assigning a grade of 1 to 4 to each region according to the mean concentration of each toxic element, as follows: 1 if the mean level of the region was below the lower quartile, 2 if it was between the lower quartile and the overall mean, 3 if it was between the overall mean and the upper quartile, and 4 if it was higher than the upper quartile. The four grades were added for each region to get an overall grade, which was compared among regions.

\section{RESULTS}

A total of 66 samples of sea lion tympanic bulla were analyzed from 10 rookeries (4 regions) in the Gulf of California. The trace elements with highest concentration were $\mathrm{Al}$, with an overall mean of $73.70 \mu \mathrm{g} \mathrm{g}^{-1}$, Zn with $60.78 \mu \mathrm{g} \mathrm{g}^{-1}$, and $\mathrm{Fe}$ with $58.81 \mu \mathrm{g} \mathrm{g}^{-1}$. $\mathrm{Hg}\left(0.11 \mu \mathrm{g} \mathrm{g}^{-1}\right)$ and $\mathrm{Cd}\left(2.99 \mu \mathrm{g} \mathrm{g}^{-1}\right)$ showed the lowest concentrations (table 1).

\section{Concentration of trace elements in the different regions}

Only the concentration of As and $\mathrm{Hg}$ showed significant differences among regions (As: $H=13.07$, d.f. $=3$, elementos traza, se seleccionaron los cuatro elementos traza altamente tóxicos: $\mathrm{As}, \mathrm{Cd}, \mathrm{Hg}$ y $\mathrm{Pb}$. Debido a que no hay datos disponibles sobre el nivel umbral para $Z$. californianus u otras especies de otáridos, se compararon las regiones de colonias de lobos marinos. Esta comparación se llevó a cabo mediante la asignación de una calificación del 1 al 4 a cada región de acuerdo con la concentración promedio de cada elemento tóxico: (1) si el nivel promedio de la región estaba por debajo del cuartil inferior, (2) si estaba entre el cuartil inferior y la media, (3) si estaba entre la media y el cuartil superior, y (4) si era mayor que el cuartil superior. Las cuatro calificaciones se sumaron para cada región para obtener una calificación global, que se comparó entre las regiones.

\section{RESUlTADOS}

Se analizaron en total 66 muestras de bula timpánica de lobos marinos provenientes de 10 colonias (4 regiones) en el golfo de California. Los elementos traza con mayor concentración fueron el $\mathrm{Al}$, con una media global de $73.70 \mu \mathrm{g} \mathrm{g}^{-1}$, el $\mathrm{Zn}$ con $60.78 \mu \mathrm{g} \mathrm{g}^{-1}$ y el Fe con $58.81 \mu \mathrm{g} \mathrm{g}^{-1}$. El $\mathrm{Hg}\left(0.11 \mu \mathrm{g} \mathrm{g}^{-1}\right)$ y el Cd $\left(2.99 \mu \mathrm{g} \mathrm{g}^{-1}\right)$ mostraron las menores concentraciones (tabla 1 ).

\section{Concentración de los elementos traza en las distintas regiones}

Sólo las concentraciones de As y $\mathrm{Hg}$ mostraron diferencias significativas entre regiones (As: $H=13.07$, d.f. $=3, P=$ 0.004 ; y Hg: $H=19.93$, d.f. $=3, P<0.001$ ). El As fue significativamente mayor en la región Golfo Central que en Golfo Norte $(Z=-2.219, P=0.026)$ y Ángel de la Guarda $(Z=$ $-2.15, P=0.031)$. El $\mathrm{Hg}$ fue significativamente mayor en Golfo Norte que en Golfo Central $(Z=2.458, P=0.014)$, y en Ángel de la Guarda que en Golfo Central $(Z=3.712, P<$ $0.001)$ y en Golfo Sur $(Z=3.037, P=0.002)$. Adicionalmente, el $\mathrm{Fe}$ fue significativamente más alto en Ángel de la Guarda que en Golfo Central $(Z=2.039, P=0.041)$.

La región Golfo Central mostró concentraciones máximas, aunque no significativas, de cinco elementos traza (As, $\mathrm{Cd}, \mathrm{Co}, \mathrm{Pb}$ y $\mathrm{Zn}$ ); tres elementos fueron máximos en Golfo Sur (Cu, Ni y Se), dos en Ángel de la Guarda ( $\mathrm{Al}$ y Fe) y sólo Hg en Golfo Norte. Además, Ángel de la Guarda exhibió concentraciones mínimas de cuatro elementos (Co, $\mathrm{Cu}, \mathrm{Ni}$ y Se) (fig. 1).

\section{Relación con datos de dieta}

Cuatro especies de peces, Caulolatilus princeps, Mugil cephalus, Roncador stearnsii y Selar crumenophthalmus, son presas de los lobos marinos y además se han monitoreado para conocer su concentración de elementos traza en la costa de Sinaloa (Golfo Sur) (tabla 2). El Pb fue alto en C. princeps en el sudeste del golfo de California (Ruelas-Inzunza et al. 2010); sin embargo, ésta especie no fue una presa importante 
Table 1. Mean concentration \pm standard deviation of 11 trace elements ( $\mu \mathrm{g} \mathrm{g}^{-1}$ dry weight) in tympanic bulla of California sea lions from 10 rookeries in the Gulf of California. The sample size for each region is indicated in parentheses; total $n=66$.

Tabla 1. Concentración media \pm desviación estándar de 11 elementos traza ( $\mu \mathrm{g} \mathrm{g}^{-1}$ de peso seco) en la bola timpánica de lobo marino de California de 10 colonias en el golfo de California. Los paréntesis encierran el tamaño de muestra para cada región; total $n=66$.

\begin{tabular}{|c|c|c|c|c|}
\hline Element & \multicolumn{4}{|c|}{ Region } \\
\hline $\mathrm{Al}$ & $63.69 \pm 51.16$ & $92.99 \pm 109.33$ & $71.71 \pm 77.11$ & $62.73 \pm 44.46$ \\
\hline As & $0.00 \pm 0.00^{\mathrm{a}}$ & $1.20 \pm 4.96^{\mathrm{b}}$ & $29.66 \pm 52.95^{\mathrm{a}, \mathrm{b}}$ & $16.48 \pm 39.92$ \\
\hline $\mathrm{Cd}$ & $2.61 \pm 1.76$ & $2.63 \pm 1.25$ & $3.57 \pm 2.68$ & $2.59 \pm 1.84$ \\
\hline $\mathrm{Co}$ & $27.05 \pm 34.95$ & $24.54 \pm 27.43$ & $45.94 \pm 41.37$ & $30.48 \pm 35.93$ \\
\hline $\mathrm{Hg}$ & $0.16 \pm 0.29^{\mathrm{a}}$ & $0.15 \pm 0.14^{\mathrm{b}, \mathrm{c}}$ & $0.02 \pm 0.05^{\mathrm{a}, \mathrm{b}}$ & $0.04 \pm 0.04^{c}$ \\
\hline $\mathrm{Fe}$ & $59.10 \pm 58.69$ & $74.95 \pm 61.64^{\mathrm{d}}$ & $38.71 \pm 25.33^{\mathrm{d}}$ & $70.51 \pm 68.40$ \\
\hline $\mathrm{Ni}$ & $33.11 \pm 22.55$ & $31.42 \pm 11.74$ & $33.08 \pm 29.52$ & $45.33 \pm 25.26$ \\
\hline $\mathrm{Pb}$ & $28.25 \pm 12.37$ & $28.26 \pm 5.77$ & $28.98 \pm 16.67$ & $25.67 \pm 12.87$ \\
\hline
\end{tabular}

Superscript letters indicate significant differences between pairs of regions (Mann-Whitney $U$ test).

$P=0.004 ; \mathrm{Hg}: H=19.93$, d.f. $=3, P<0.001)$. As was significantly higher in the Central Gulf than in the Northern Gulf $(Z=-2.219, P=0.026)$ and Ángel de la Guarda $(Z=-2.15, P=0.031)$. Hg was significantly higher in the Northern Gulf than in the Central Gulf $(Z=2.458, P=$ $0.014)$, and in Ángel de la Guarda than in the Central Gulf $(Z=3.712, P<0.001)$ and the Southern Gulf $(Z=3.037, P=$ $0.002)$. Additionally, Fe was significantly higher in Ángel de la Guarda than in the Central Gulf $(Z=2.039, P=0.041)$.

Although non-significant, the Central Gulf showed maximum concentrations of five trace elements ( $\mathrm{As}, \mathrm{Cd}, \mathrm{Co}, \mathrm{Pb}$, and $\mathrm{Zn})$, three elements in the Southern Gulf $(\mathrm{Cu}, \mathrm{Ni}$, and $\mathrm{Se}$ ), two in Ángel de la Guarda ( $\mathrm{Al}$ and $\mathrm{Fe}$ ), and only $\mathrm{Hg}$ in the Northern Gulf. Furthermore, Ángel de la Guarda showed minimum mean concentrations of four elements $(\mathrm{Co}, \mathrm{Cu}, \mathrm{Ni}$, and Se) (fig. 1).

\section{Relation with diet data}

Four fish species, Caulolatilus princeps, Mugil cephalus, Roncador stearnsii, and Selar crumenophthalmus, are prey of sea lions and have been monitored for trace element concentrations along the Sinaloan coast (Southern Gulf) (table 2). $\mathrm{Pb}$ was high in C. princeps in the SE Gulf of California (Ruelas-Inzunza et al. 2010); however, this species was not an important prey in sea lion rookeries (less than $4 \%$ of the index of importance) in the Southern Gulf (Porras-Peters et al. 2008). Roncador stearnsii showed low $\mathrm{Cu}$ and $\mathrm{Cd}$, and high Hg levels (Ruelas-Inzunza et al. 2008, 2010) in the Farallón de San Ignacio sea lion rookery (Southern Gulf) with low importance in the diet (Porras-Peters et al. 2008). On the other hand, S. crumenophthalmus was consumed in en las colonias de lobo marino en la región Golfo Sur (menos que el 4\% del índice de importancia) (Porras-Peters et al. 2008). Roncador stearnsii mostró concentraciones de $\mathrm{Cu}$ y Cd bajas y de Hg altas (Ruelas-Inzunza et al. 2008, 2010) en la colonia de lobos marinos de Farallón de San Ignacio (Golfo Sur) con baja importancia en la dieta (Porras-Peters et al. 2008). Por otro lado, S. crumenophthalmus fue consumida en la región Golfo Sur (Porras-Peters et al. 2008) y mostró la mayor concentración de $\mathrm{Cu}$ en peces de esa región; en esta especie $\mathrm{Cu}, \mathrm{Cd}$ y $\mathrm{Pb}$ se encontraron en concentraciones ligeramente mayores que en $C$. princeps y $R$. stearnsii (Ruelas-Inzunza et al. 2010). Mugil cephalus mostró concentraciones bajas de $\mathrm{Hg}$, concentraciones intermedias de $\mathrm{Cu}$ y $\mathrm{Cd}$, y concentraciones altas de $\mathrm{Pb}$ (Ruelas-Inzunza et al. 2008,2010 ), aunque esta especie tuvo poca importancia en la dieta de los lobos marinos en esta región (tabla 2).

\section{Evaluación de la salud de las regiones}

En la tabla 3 se muestran la concentración media de los elementos traza tóxicos y las calificaciones para cada región. La región Golfo Norte presentó las concentraciones más altas de $\mathrm{Hg}$ en tejido óseo de lobo marino, mientras que Golfo Central presentó las más bajas. Por otro lado, la región Golfo Central mostró altas concentraciones de As y $\mathrm{Cd}$, y en total fue la región con la calificación de polución más alta (tabla 3).

\section{DISCUSIÓN}

Este estudio documenta la concentración de 11 elementos traza en la bula timpánica del lobo marino de California de 
Table 2. Index of importance of fish species found in the diet of sea lions at different rookeries from each region, and the trace metals (concentration) found in these species according to studies undertaken along the coast of Sinaloa (southern Gulf of California). Regions: SG, Southern Gulf; AG, Ángel de la Guarda; NG, Northern Gulf.

Tabla 2. Índice de importancia de especies de peces encontradas en la dieta de lobo marino en diferentes colonias de cada región, y los metales traza (concentración) que se encontraron en estas especies según estudios realizados en la costa de Sinaloa (Golfo Sur). Regiones: SG, Golfo Sur; AG, Ángel de la Guarda; NG, Golfo Norte.

\begin{tabular}{|c|c|c|c|}
\hline Region & Fish species & Importance in diet at rookery & Trace metals $\left(\mu \mathrm{g} \mathrm{g}^{-1}\right)$ at Sinaloa study sites* \\
\hline SG & Selar crumenophthalmus & $\begin{array}{l}5.60 \% \text { at Farallón de San Ignacio, } \\
0.59 \% \text { at Los Islotes }{ }^{1}\end{array}$ & $\begin{array}{l}{ }^{2} \mathrm{Hg}(0.3-1.6) \text { at TOP } \\
{ }^{3} \mathrm{Cu}(4.38), \mathrm{Cd}(1.59), \mathrm{Pb}(3.37) \text { at TOP }\end{array}$ \\
\hline SG & Roncador stearnsii & $5.10 \%$ at Farallón de San Ignacio ${ }^{1}$ & $\begin{array}{l}{ }^{2} \mathrm{Hg}(0.5-2.7) \text { at TOP } \\
{ }^{3} \mathrm{Cu}(3.33), \mathrm{Cd}(1.29), \mathrm{Pb}(2.86) \text { at TOP }\end{array}$ \\
\hline SG & Paralichthys sp. ${ }^{\dagger}$ & $5.56 \%$ at Farallón de San Ignacio ${ }^{1}$ & $\begin{array}{l}{ }^{2} \mathrm{Hg}(0.5-1.8) \text { at TOP } \\
{ }^{3} \mathrm{Cu}(3.11), \mathrm{Cd}(1.19), \mathrm{Pb}(4.17) \text { at TOP }\end{array}$ \\
\hline $\mathrm{AG}$ & Mugil cephalus & $6.0 \%$ at Los Machos ${ }^{1}$ & $\begin{array}{l}{ }^{2} \mathrm{Hg}(0.2-1.0) \text { at } \mathrm{TOP} ; \mathrm{Hg}(0.2-1.4) \text { at } \mathrm{AEP} \\
{ }^{3} \mathrm{Cu}(3.27), \mathrm{Cd}(1.39), \mathrm{Pb}(3.39) \text { at } \mathrm{AEP} ; \mathrm{Cu}(3.44) \text {, } \\
\mathrm{Cd}(1.98), \mathrm{Pb}(3.28) \text { at } \mathrm{TOP}\end{array}$ \\
\hline
\end{tabular}

* Study sites: TOP, Topolobampo Lagoon (northern Sinaloa); AEP, Altata Ensenada del Pabellón Lagoon (central Sinaloa); and SML, Santa María Lagoon (north-central Sinaloa).

${ }^{\dagger}$ Paralichthys sp. corresponds to Paralichthys californicus in sea lion's diet ${ }^{1}$, and Paralichthys woolmani studied in Sinaloa. Haemulopsis sp. corresponds to Haemulopsis leuciscus in sea lion's diet ${ }^{1}$, and Haemulopsis axillaris studied in Sinaloa.

${ }^{1}$ Porras-Peters (2004), ${ }^{2}$ Ruelas-Inzunza et al. (2008), ${ }^{3}$ Ruelas-Inzunza et al. (2010).

the Southern Gulf (Porras-Peters et al. 2008) and this species showed the highest $\mathrm{Cu}$ levels in fish from that region; in this species $\mathrm{Cu}, \mathrm{Cd}$, and $\mathrm{Pb}$ were found in slightly higher concentrations than in C. princeps and $R$. stearnsii (Ruelas-Inzunza et al. 2010). Mugil cephalus showed low values of $\mathrm{Hg}$, medium values of $\mathrm{Cu}$ and $\mathrm{Cd}$, and high values of $\mathrm{Pb}$ (RuelasInzunza et al. 2008, 2010), although this species had low importance in the sea lion diet in this region (table 2).

\section{Regional health assessment}

Mean levels of the toxic trace elements and the grades for each region are shown in table 3. The Northern Gulf had the highest $\mathrm{Hg}$ values for sea lion bone tissue, while the Central Gulf had the lowest. On the other hand, the Central Gulf showed high levels of As and $\mathrm{Cd}$, and overall was the region with the highest general pollution grade (table 3 ).

\section{DISCUSSION}

This study reports the concentration of 11 trace elements from tympanic bulla of California sea lions from 10 rookeries
10 colonias en cuatro regiones diferentes del golfo de California. Nuestros resultados muestran algunas diferencias en las concentraciones medias de los elementos traza entre las regiones. Los metales que presentaron las mayores concentraciones promedio no fueron los más tóxicos $(\mathrm{Al}, \mathrm{Zn}$ y Fe con concentraciones medias $>45 \mu \mathrm{g} \mathrm{g}^{-1}$ ).

$\mathrm{Se}$ han registrado intervalos de variación de $\mathrm{Cu}, \mathrm{Fe}, \mathrm{Hg}$, $\mathrm{Se}, \mathrm{Pb}$ y $\mathrm{Zn}$ más amplios en muestras de pelo de crías del lobo marino en ocho colonias (Elorriaga-Verplancken y Aurioles-Gamboa 2008). Esta gran variabilidad puede deberse a la alta tasa de renovación del tejido analizado. En general, las concentraciones medias fueron mayores en pelo que en el tejido óseo analizado en nuestro estudio. Por ejemplo, el Hg (6.55-14.10 $\left.\mu \mathrm{g} \mathrm{g}^{-1}\right)$, el Fe (74.8-208 $\left.\mu \mathrm{g} \mathrm{g}^{-1}\right)$ y el $\mathrm{Zn}\left(40.5-398 \mu \mathrm{g} \mathrm{g}^{-1}\right)$ fueron todos más altos en pelo en comparación con nuestros resultados. Sin embargo, excepto en tres colonias, el $\mathrm{Pb}$ tendió a ser más bajo en pelo (5.1-44.4 $\mu \mathrm{g} \mathrm{g}^{-1}$ ) que en bula (Elorriaga-Verplancken y Aurioles-Gamboa 2008), lo que puede explicarse por la afinidad específica del $\mathrm{Pb}$ con el tejido óseo (Eisler 2010). La concentración media de $\mathrm{Cu}$ y $\mathrm{Se}$ en pelo de crías de lobo marino fueron similares a nuestro estudio. 
in four different regions of the Gulf of California. Our results show some differences in mean trace element concentrations among regions. Additionally, the elements that presented higher mean concentrations were not the most toxic $(\mathrm{Al}, \mathrm{Zn}$, and Fe with mean concentrations $>45 \mu \mathrm{g} \mathrm{g}^{-1}$ ).

Broader variability ranges have been reported for $\mathrm{Cu}$, $\mathrm{Fe}, \mathrm{Hg}, \mathrm{Se}, \mathrm{Pb}$, and $\mathrm{Zn}$ in hair samples from sea lion pups from eight rookeries (Elorriaga-Verplancken and AuriolesGamboa 2008). This high variability could be due to the higher turnover rate of the tissue analyzed. In general, mean concentrations were higher in hair than in our study using bone. For example, $\mathrm{Hg}\left(6.55-14.10 \mu \mathrm{g} \mathrm{g}^{-1}\right), \mathrm{Fe}(74.8-208 \mu \mathrm{g}$ $\left.\mathrm{g}^{-1}\right)$, and $\mathrm{Zn}\left(40.5-398 \mu \mathrm{g} \mathrm{g}^{-1}\right)$ were all higher in hair compared to our results; however, except in three rookeries, $\mathrm{Pb}$ tended to be lower in hair (5.1-44.4 $\left.\mathrm{g} \mathrm{g} \mathrm{g}^{-1}\right)$ than in bulla (Elorriaga-Verplancken and Aurioles-Gamboa 2008), which may be explained by the specific affinity of $\mathrm{Pb}$ to bone tissue (Eisler 2010). Mean Cu and Se concentrations in sea lion pup hair were similar to our study.

\section{Distribution of trace elements in the Gulf of California}

The determination of four ecological regions in the Gulf of California was based on a multivariate regionalization that included ecological, physical, and biogeochemical variables (Szteren and Aurioles-Gamboa 2011). These four regions were also identified based on photosynthetic pigments and other environmental and oceanographic similarities (LluchCota and Arias-Aréchiga 2000). Metal content in bone and diet diversity, however, were the most important features for defining these regions (Szteren and Aurioles-Gamboa 2011). These zones may indicate differences in feeding habits and/or different oceanographic conditions exploited by sea lions. Four groups of rookeries were also described based upon the identification of prey items (García-Rodríguez and AuriolesGamboa 2004): one in the north of the gulf, two at Ángel de la Guarda (Los Machos and Isla Granito), and the fourth in the central and southern gulf.

It is difficult to discern clear associations between regional trace element levels in sea lions and environmental concentrations. Sediment data cannot be straightforwardly related to concentrations measured in sea lion bone, firstly because of the time span from when the elements are in the sediments to when they reach the sea lions, and secondly due to the trophic levels involved. Hence, spatial and temporal lags are expected.

High levels of certain trace elements may possibly be correlated with their concentration in sediments in nearby areas in the Gulf of California. For example, Al enrichment in sediments was reported on the western coast of the Upper Gulf (Daesslé et al. 2004), coinciding with the high values found in the area of Ángel de la Guarda in this study. Also, sediments from the Colorado River delta were rich in Ni (Daesslé et al. 2004), which was high in the northern rookeries.
Table 3. Pollution grade, from 1 (lower) to 4 (higher), for each environmental region of the Gulf of California (NG, Northern Gulf; AG, Ángel de la Guarda; CG, Central Gulf; and SG, Southern Gulf) according to the mean concentration of four trace elements, and the upper and lower quartiles ( $\mu \mathrm{g} \mathrm{g}^{-1}$ dry weight).

Tabla 3. Calificación de polución, del 1 (inferior) al 4 (superior), para cada región del golfo de California (NG, Golfo Norte; AG, región Ángel de la Guarda; CG, Golfo Central y SG, región Golfo Sur) según la concentración media de cuatro elementos traza, y los cuartiles superior e inferior $\left(\mu \mathrm{g} \mathrm{g}^{-1}\right.$ de peso seco).

\begin{tabular}{lcccc}
\hline \multirow{2}{*}{ Region } & \multicolumn{4}{c}{ Grade } \\
\cline { 2 - 5 } & $\mathrm{As}$ & $\mathrm{Cd}$ & $\mathrm{Hg}$ & $\mathrm{Pb}$ \\
\hline $\mathrm{NG}$ & 1 & 2 & 4 & 3 \\
$\mathrm{AG}$ & 1 & 2 & 3 & 3 \\
$\mathrm{CG}$ & 4 & 4 & 1 & 3 \\
$\mathrm{SG}$ & 3 & 2 & 2 & 2 \\
\hline Mean & 11.37 & 2.81 & 0.09 & 28.14 \\
Lower quartile & 0.00 & 2.20 & 0.03 & 24.81 \\
Upper quartile & 16.53 & 3.07 & 0.15 & 29.93 \\
\hline
\end{tabular}

\section{Distribución de elementos traza en el golfo de California}

La determinación de cuatro regiones ecológicas en el golfo de California se basó en una regionalización de análisis multivariado que incluyó variables ecológicas, físicas y biogeoquímicas (Szteren y Aurioles-Gamboa 2011). Estas cuatro regiones también fueron identificadas de acuerdo con los pigmentos fotosintéticos y otras similitudes ambientales y oceanográficas (Lluch-Cota y Arias-Aréchiga 2000). Sin embargo, el contenido de metales en hueso y la diversidad de dieta fueron los aspectos más relevantes para la definición de estas regiones (Szteren y Aurioles-Gamboa 2011). Estas zonas pueden indicar diferencias en los hábitos alimentarios y/o las condiciones oceanográficas diferentes explotadas por los lobos marinos. Con base en la identificación de ítems presa, también se describieron cuatro grupos de colonias (García-Rodríguez y Aurioles-Gamboa 2004): un grupo en el norte del golfo, dos en Ángel de la Guarda (Los Machos e Isla Granito) y el cuarto en el centro y sur del golfo.

Es difícil discernir asociaciones claras entre las concentraciones de elementos traza en el lobo marino y las concentraciones ambientales a nivel regional. Los datos en sedimentos no pueden ser relacionados directamente con las concentraciones medidas en el hueso de los lobos marinos debido, en primer lugar, al periodo de tiempo desde que los elementos estaban en los sedimentos hasta que llegaron al lobo marino y, en segundo lugar, a los niveles tróficos implicados. Por lo tanto, se esperaría que existan desfases espaciales y temporales.

Los altos niveles de ciertos elementos traza posiblemente pueden correlacionarse con su concentración en los sedimentos en áreas cercanas dentro del golfo. Por ejemplo, se ha 
The Northern Gulf is very shallow (less than $200 \mathrm{~m}$ ) (Carrillo and Palacios-Hernández 2002, Marinone 2003) and is nutrient-enriched due to strong tidal currents, high turbidity, thick sediments, extreme temperatures, high evaporation, and salinity (Maluf 1983). Also in the north, a separate area around Ángel de la Guarda Island has been proposed (LluchCota and Arias Aréchiga 2000, Lluch-Cota 2004) because of its unique topographic and oceanographic conditions. It is characterized by strong tidal currents, high vertical mixing, low surface temperatures, and high productivity levels (Maluf 1983). In addition, mean southward or surface flows in the gulf renew waters and contribute to generate upwelling (López et al. 2006). In this study, the highest level of Fe as well as the greatest amounts of macroalgae were measured in the Ángel de la Guarda region; this is probably due to intense vertical mixing in the area (Huerta-Díaz et al. 2007).

The Central Gulf (from Tiburón Island southwards to La Paz-Topolobampo) has several basins, low tidal amplitude, and important seasonal upwelling (Maluf 1983). It is greatly influenced by winds. Gyres and filaments transport cold and chlorophyll-rich waters from east to west (Navarro-Olache et al. 2004). Abnormally high sediment concentrations of $\mathrm{Cu}$, $\mathrm{Co}$, and $\mathrm{Zn}$ were found in the vicinity of Santa Rosalía, Baja California Sur (Central Gulf) (Shumilin et al. 2000). A comparison of the elements in tympanic bulla of sea lions revealed that $\mathrm{Co}$ and $\mathrm{Zn}$ were maximum in the Central Gulf. Additionally, $\mathrm{Cd}$ may be high in predators feeding on Cephalopods (Bustamante et al. 1998), which may explain the high $\mathrm{Cd}$ concentrations in the Central Gulf where squid (Dosidicus gigas) is an important dietary item (e.g., San Pedro Nolasco rookery, Porras-Peters et al. 2008). In two Cetacean species stranded in the SE Gulf of California, Fe showed the highest mean concentration compared to five other trace elements $(\mathrm{Cd}, \mathrm{Co}, \mathrm{Mn}, \mathrm{Pb}$, and $\mathrm{Zn})$ in muscle, liver, and kidney (5200 ${\mu \mathrm{g} \mathrm{g}^{-1}}^{-1}$ Physeter catodon liver and $1009 \mu \mathrm{g} \mathrm{g}^{-1}$ in Eschrichthius robustus muscle) (RuelasInzunza and Páez-Osuna 2002).

Finally, the Southern Gulf exhibits more oceanic conditions, with high slopes, low salinity, and greater rainfall (Maluf 1983). Fronts commonly develop at the mouth, making this area important for fisheries (Álvarez-Borrego 1983). $\mathrm{Cu}, \mathrm{Ni}$ and Se were high in sea lions from the Southern Gulf, while sediments from southern Sinaloa were enriched in $\mathrm{Cu}$ (Soto-Jiménez et al. 2003).

These differences may be relevant to characterize the environmental conditions of these areas and to highlight that further studies should determine trace element persistence and origin.

\section{Pollution situation in each region}

No information is available regarding the long-term effects or the physiological consequences of trace elements in sea lions. Some trace elements act as antagonists to others; consequently, a link between metal concentrations and registrado el enriquecimiento de $\mathrm{Al}$ en sedimentos de la costa oeste del alto golfo (Daesslé et al. 2004), coincidiendo con altos valores hallados en el área de Ángel de la Guarda en éste estudio. Además, los sedimentos del delta del río Colorado eran ricos en Ni (Daesslé et al. 2004), que fue alto en las colonias del norte.

La región Golfo Norte es muy somera (menos de $200 \mathrm{~m}$ ) (Carrillo y Palacios-Hernández 2002, Marinone 2003) y está enriquecida con nutrientes debido a las fuertes corrientes de marea, la gran turbidez, los sedimentos gruesos, las temperaturas extremas, la alta evaporación y la salinidad (Maluf 1983). También en el norte, se ha propuesto un área separada alrededor de la isla Ángel de la Guarda (Lluch-Cota y Arias Aréchiga 2000, Lluch-Cota 2004) debido a su topografía y condiciones oceanográficas únicas. Se caracteriza por las fuertes corrientes de marea, la gran mezcla vertical, las bajas temperaturas superficiales y los altos niveles de productividad (Maluf 1983). Adicionalmente, los flujos medios hacia el sur o superficiales en el golfo renuevan las aguas y contribuyen a generar surgencias (López et al. 2006). Por otra parte, en éste estudio, en la región Ángel de la Guarda se midió la concentración más alta de $\mathrm{Fe}$ y se registró la cantidad más alta de macroalgas muestreadas; esto probablemente se deba a la intensa mezcla vertical en la zona (Huerta-Díaz et al. 2007).

La región Golfo Central (desde la isla Tiburón hacia el sur hasta La Paz-Topolobampo) tiene varias cuencas, baja amplitud de mareas e importantes surgencias estacionales (Maluf 1983). Está muy influenciada por los vientos. Los giros y filamentos transportan aguas frías y ricas en clorofila desde el este al oeste (Navarro-Olache et al. 2004). En los alrededores de Santa Rosalía, Baja California Sur (Golfo Central), se encontraron concentraciones anormalmente altas de $\mathrm{Cu}, \mathrm{Co}, \mathrm{y} \mathrm{Zn}$ (Shumilin et al. 2000). Comparando con el contenido de elementos traza en bula timpánica de lobo marino, el Co y el Zn fueron máximos en Golfo Central. Adicionalmente, el Cd puede ser alto en depredadores que se alimentan de cefalópodos (Bustamante et al. 1998), lo que puede explicar las altas concentraciones de $\mathrm{Cd}$ en Golfo Central, donde el calamar (Dosidicus gigas) es una presa importante en la dieta (e.g., colonia San Pedro Nolasco, Porras-Peters et al. 2008). En dos especies de cetáceos varados en el sureste del golfo de California, el Fe mostró la mayor concentración media, entre otros cinco elementos traza ( $\mathrm{Cd}, \mathrm{Co}, \mathrm{Mn}, \mathrm{Pb}$ y $\mathrm{Zn}$ ), en el músculo, hígado y riñón (5200 $\mu \mathrm{g} \mathrm{g}^{-1}$ en hígado de Physeter catodon y $1009 \mu \mathrm{g} \mathrm{g}^{-1}$ en músculo de Eschrichthius robustus (Ruelas-Inzunza y PáezOsuna 2002).

Finalmente, la región Golfo Sur exhibe condiciones más oceánicas, con pendientes altas, baja salinidad y altas precipitaciones (Maluf 1983). Comúnmente se desarrollan frentes en la boca, lo que hace a esta área importante para las pesquerías (Alvarez-Borrego 1983). El Cu, Ni y Se fueron altos en lobos marinos del sur del golfo de California, mientras que 
animal health is very complex to depict. Furthermore, there might be mechanisms by which the animal eliminates the excess of trace elements, hence their high concentration does not necessarily imply health problems (Ikemoto et al. 2004).

No metabolic data are available in order to establish if the levels found are excessive or at least have negative effects on the animals. With the information gathered we can only establish which rookeries have higher or lower levels of trace elements. In this sense, we could hypothesize that sea lions at rookeries with high mean levels would be more susceptible to have or acquire health problems in the future.

Our results indicated that the Southern Gulf showed lower concentrations of toxic trace metals suggesting better conditions in terms of pollution, while attention should be placed on the Central Gulf, especially regarding As and $\mathrm{Cd}$, and on the Northern Gulf, concerning Hg. These results are relevant with regards to conservation issues of Z. californianus in the Gulf of California where some populations have shown clear signs of decrease over the last 20 years (Szteren et al. 2006, Ward et al. 2010). There is no basic information about ailments caused by trace element content in order to establish the threshold levels associated with particular health problems. In this sense, the grading system was useful as a general approach to compare element concentrations among rookery regions and determine areas where sea lion rookeries may potentially show long-term health problems associated with the chronic accumulation of trace elements. Since some sea lion rookeries are more susceptible to health problems than others, the approximation used in this study should be taken into consideration as a precautionary indicator for management.

\section{ACKNOWLEDGMENTS}

This study was supported by the Instituto Politécnico Nacional (Mexico) through the Environmental Network project "Estado de salud, uso sustentable y conservación del Golfo de California" and project SIP-20120061-20130363 "Valores isotópicos de carbono y nitrógeno y estimación de niveles tróficos de organismos marinos frente a Bahía Magdalena". We aknowledge the Dirección General de Vida Silvestre for granting research permits during several years to collect bone material in the Gulf of California. Thanks to the three anonymous referees for their valuable comments.

\section{REFERENCES}

Álvarez-Borrego S. 1983. Gulf of California. In: Ketchum BH (ed.), Ecosystems of the World. 26. Estuaries and Enclosed Seas. Elsevier Scientific, Amsterdam, pp. 427-449.

Aurioles-Gamboa D, Zavala-González A. 1994. Algunos factores ecológicos que determinan la distribución y abundancia del lobo marino Zalophus californianus, en el Golfo de California. Cienc. Mar. 20: 535-553.

Aurioles-Gamboa D, Newsome SD, Salazar-Pico S, Koch PL. 2009. Stable isotope differences between sea lions (Zalophus) from los sedimentos del sur de Sinaloa estuvieron enriquecidos de $\mathrm{Cu}$ (Soto-Jiménez et al. 2003).

Estas diferencias pueden ser relevantes para caracterizar las condiciones ambientales de estas áreas y resaltar que en futuros estudios se determine la persistencia y origen de los elementos traza.

\section{Estado de polución en cada región}

No hay información disponible sobre los efectos a largo plazo o las consecuencias fisiológicas de los elementos traza en el lobo marino. Algunos elementos traza son antagonistas de otros; en consecuencia, resulta muy complejo poder establecer un vínculo entre las concentraciones de metales y la salud de los animales. Además, pueden haber mecanismos por los cuales los animales eliminan el exceso de elementos traza, por lo tanto, su alta concentración no implica necesariamente la existencia de problemas de salud (Ikemoto et al. 2004).

No existen datos metabólicos para poder establecer si los niveles encontrados son excesivos o están teniendo un efecto negativo en los organismos. Con la información recolectada sólo podemos establecer cúales colonias tienen mayores o menores concentraciones de elementos traza. En éste sentido, se puede hipotetizar que los lobos marinos en colonias con altas concentraciones medias serían más susceptibles a tener $\mathrm{o}$ adquirir problemas de salud en el futuro.

Nuestros resultados indicaron que el sur del golfo de California mostró menor concentración de elementos traza, sugiriendo mejores condiciones en términos de polución, mientras que se debería poner atención a la región Golfo Central, especialmente en lo que respecta al As y al Cd, y a la región Golfo Norte, en relación con el Hg. Estos resultados son relevantes respecto a la conservación de Z. californianus en el golfo de California, que tiene algunas colonias con claros signos de decrecimiento en los últimos 20 años (Szteren et al. 2006, Ward et al. 2010). No hay información básica acerca de las afecciones causadas por el contenido de elementos traza que permita establecer los niveles umbrales asociados con problemas de salud particulares. En este sentido, el sistema de calificaciones fue útil como aproximación general para comparar las concentraciones de elementos entre regiones de colonias y determinar áreas donde las colonias de lobos marinos pueden potencialmente mostrar problemas de salud a largo plazo asociados con la acumulación crónica de elementos traza. Dado que algunas colonias de lobo marino serían más susceptibles a tener problemas de salud que otras, la aproximación usada en este estudio debería considerarse como un indicador precautorio para el manejo.

\section{Agradecimientos}

Gracias al apoyo del Instituto Politécnico Nacional (México) a través del proyecto de la Red del Medio 
the Gulf of California and Galapagos Islands. J. Mammal. 90: $1410-1420$

http://dx.doi.org/10.1644/08-MAMM-A-209R2.1

Baraj B, Niencheski LF, Windom H, Hermanns L. 2009. Trace metal concentration in liver, kidney and heart in South American fur seal (Arctocephalus australis) from Southern Brazil. Mar. Pollut. Bull. 58: 1948-1952. http://dx.doi.org/10.1016/j.marpolbul.2009.07.026

Braham HW. 1973. Lead in the California sea lion (Zalophus californianus). Environ. Pollut. 5: 253-258.

Bustamante P, Caurant F, Fowler SW, Miramand P. 1998. Cephalopods as a vector for the transfer of cadmium to top marine predators in the north-east Atlantic Ocean. Sci. Total Environ. 220: 71-80.

Carrillo L, Palacios-Hernández E. 2002. Seasonal evolution of the geotropic circulation in the northern Gulf of California. Estuar. Coast. Shelf Sci. 54: 157-173. http://dx.doi.org/10.1006/ecss.2001.0845

Daesslé LW, Camacho-Ibar VF, Carriquiry JD, Ortiz-Hernández MC. 2004. The geochemistry and sources of metals and phosphorus in the recent sediments from the Northern Gulf of California. Cont. Shelf Res. 24: 2093-2106. http://dx.doi.org/10.1016/j.csr.2004.06.022

Eisler R. 1987. Mercury hazards to fish, wildlife and invertebrates: A synoptic review. US Fish Wildl. Serv. Biol. Rep. 85(10), Contaminant Hazard Rev. 10, 63 pp.

Eisler R. 1988. Arsenic hazards to fish, wildlife, and invertebrates. A synoptic review. US Fish Wildl. Serv. Biol. Rep. 85(1.12), $92 \mathrm{pp}$.

Eisler R. 2010. Compendium of trace metals and marine biota. Vol. 2. Vertebrates. Elsevier. Oxford, UK.

Elorriaga-Verplancken F, Aurioles-Gamboa D. 2008. Trace metal concentrations in the hair of Zalophus californianus pups and their relation to feeding habits. Biol. Trace Elem. Res. 126:148-164.

Fair PA, Becker PR. 2000. Review of stress in marine mammals. J. Aquat. Ecosyst. Stress Recovery 7: 335-354. http://dx.doi.org/10.1023/A:1009968113079

García-Rodríguez FJ, Aurioles-Gamboa D. 2004. Spatial and temporal variation in the diet of the California sea lion (Zalophus californianus) in the Gulf of California, Mexico. Fish. Bull. 102: 47-62.

Gdula-Argasinska J, Appleton J, Sawicka-Kapusta K, Spence B. 2004. Further investigation of the heavy metal content of the teeth of the bank vole as an exposure indicator of environmental pollution in Poland. Environ. Pollut. 131:71-79. http://dx.doi.org/10.1016/ j.envpol.2004.02.025

Geraci JR, Harwood J, Lounsbury VJ. 1999. Marine mammal dieoffs. In: Twiss JR, Reeves RR (eds.), Conservation and Management of Marine Mammals. Smithsonian Institution Press, Washington DC, pp. 367-395.

Gerpe MS, de Moreno JEA, Moreno VJ, Patat ML. 2000. Cadmium, zinc and cooper accumulation in the squid Illex argentinus from the Southwest Atlantic Ocean. Mar. Biol. 136: 1039-1044. http://dx.doi.org/10.1007/s002270000308

Huerta-Díaz MA, de León-Chavira F, Lares ML, Chee-Barragán A, Siqueiros-Valencia A. 2007. Iron, manganese and trace metal concentrations in seaweeds from the central west coast of the Gulf of California. Appl. Geochem. 11: 1380-1392. http://dx.doi.org/10.1016/j.apgeochem.2007.03.052

Ikemoto T, Kunito T, Tanaka H, Baba N, Miyazaki N, Tanabe S. 2004. Detoxification mechanism of heavy metals in marine mammals and seabirds: Interaction of selenium with mercury, silver, copper, zinc, and cadmium in liver. Arch. Environ. Contam. Toxicol. 47: 402-413.

http://dx.doi.org/10.1007/s00244-004-3188-9
Ambiente "Estado de salud, uso sustentable y conservación del Golfo de California" y el proyecto SIP-2012006120130363 "Valores isotópicos de carbono y nitrógeno y estimación de niveles tróficos de organismos marinos frente a Bahía Magdalena". Agradecemos a la Dirección General de Vida Silvestre los permisos de investigación a lo largo de varios años para la recolecta de material óseo en el golfo de California. También agradecemos a los tres revisores anónimos por sus valiosos comentarios.

Jarman WM, Hobson KA, Sydeman WJ, Bacon CE, Mclaren EB. 1996. Influence of trophic position and feeding location on contaminant levels in the Gulf of Farallones food web revealed by stable isotopes analysis. Environ. Sci. Technol. 30: 654-660. http://dx.doi.org/10.1021/es950392n

Kuhn CE. 2006. Measuring at sea feeding to understand the foraging behavior of pinnipeds. $\mathrm{PhD}$ thesis, University of Califronia, Santa Cruz, 129 pp.

Labrada-Martagón V, Aurioles-Gamboa D, Castro-González MI. 2007. Relation of dental wear to the concentrations of essential minerals in teeth of the California sea lion Zalophus californianus californianus. Biol. Trace Elem. Res. 115: 107-126. http://dx.doi.org/10.1007/BF02686023

Lluch-Cota SE. 2004. Gulf of California. Marine ecosystems of the North Pacific. PICES Spec. Pub. 1: 1-7.

Lluch-Cota SE, Arias-Aréchiga JP. 2000. Sobre la importancia de considerar la existencia de centros de actividad biológica para la regionalización del océano: El caso del Golfo de California. In: Lluch-Belda D, Elorduy-Garay J, Lluch-Cota SE, Ponce-Díaz G. (eds.), BAC Centros de Actividad Biológica del Pacífico Mexicano. CIB, CICIMAR, CONACYT, La Paz, México, pp. 255-263.

López M, Candela J, Argote ML. 2006. Why does the Ballenas Channel have the coldest SST in the Gulf of California? Geophys. Res. Lett. 33, L11603.

http://dx.doi.org/10.1029/2006GL025908

Lunde G. 1977. Occurrence and transformation of arsenic in the marine environment. Environ. Health Perspect. 19: 47-52.

Maluf LY. 1983. The physical oceanography. In: Case TJ, Cody ML (eds.), Island Biogeography in the Sea of Cortez. University of California Press, Berkeley, pp. 26-45.

Marinone SG. 2003. A three-dimensional model of the mean and seasonal circulation of the Gulf of California. J. Geophys Res. 108: 3325 . http://dx.doi.org/10.1029/2002JC001720

Navarro-Olache LF, Lavín MF, Alvarez-Sánchez LG, Zirino A. 2004. Internal structure of SST features in the central Gulf of California. Deep Sea Res. (II) 51: 673-687. http://dx.doi.org/10.1016/j.dsr2.2004.05.014

Perkin-Elmer C. 1996. Analytic Methods for Atomic Absorption Spectrophotometry. The Perkin-Elmer Company, Connecticut.

Porras-Peters HJ. 2004. Nivel, amplitud y superposición trófica de las colonias de lobo marino Zalophus californianus del Golfo de California. MSc thesis. CICIMAR, IPN, La Paz, México. 81 pp.

Porras-Peters H, Aurioles-Gamboa D, Cruz-Escalona VH, Koch PL. 2008. Trophic level and overlap of sea lions (Zalophus californianus) in the Gulf of California, Mexico. Mar. Mamm. Sci. 24: 554-576.

http://dx.doi.org/10.1111/j.1748-7692.2008.00197.x 
Reijnders P, Brasseur S, van der Toorn J, van der Wolf P, Boyd I, Harwood J, Lavigne D, Lowry L . 1993. Seals, fur seals, sea lions, and walrus. Status Survey and Conservation Action Plan. IUCN/ SSC Seal Specialist Group. Gland, Switzerland, 88 pp.

Ruelas-Inzunza J, Páez-Osuna F. 2002. Distribution of Cd, Cu, Fe, $\mathrm{Mn}, \mathrm{Pb}$ and $\mathrm{Zn}$ in selected tissues of juvenile whales stranded in the SE Gulf of California (Mexico). Environ. Int. 28: 325-329.

Ruelas-Inzunza J, Meza-López G, Páez-Osuna F. 2008. Mercury in fish that are of dietary importance from the coasts of Sinaloa (SE Gulf of California). J. Food Comp. Anal. 21: 211-218. http://dx.doi.org/10.1016/j.jfca.2007.11.004

Ruelas-Inzunza J, Páez-Osuna F, García-Flores D. 2010. Essential $(\mathrm{Cu})$ and nonessential $(\mathrm{Cd}$ and $\mathrm{Pb})$ metals in ichthyofauna from the coasts of Sinaloa state (SE Gulf of California). Environ. Monit. Assess. 162: 251-263. http://dx.doi.org/10.1007/s10661-009-0793-0

Skoch EJ. 1990. Heavy metals in marine mammals. Presence and analytical methods. In: Dierauf LA (ed.), Handbook of Marine Mammal Medicine: Health, Disease, and Rehabilitation. CRC Press, Boca Raton, Florida, pp. 127-137.

Shumilin EN, Rodríguez-Figueroa G, Morton-Bermea E, Lounejeva-Baturina E, Hernández E, Durga Rodríguez Meza G. 2000. Anomalous trace element composition of coastal sediments near the copper mining district of Santa Rosalía, peninsula of Baja California, Mexico. Bull. Environ. Contam. Toxicol. 65: 261-268. http://dx.doi.org/10.1007/s001280000123

Soto-Jiménez M, Páez-Osuna F, Ruiz-Fernández AC. 2003. Geochemical evidences of the anthropogenic alteration of trace metal composition of the sediments of Chiricahueto marsh (SE Gulf of California). Environ. Pollut. 125: 423-432. http://dx.doi.org/10.1016/S0269-7491(03)00083-6
Sydeman WJ, Jarman WM. 1998. Trace metals in seabirds, Steller sea lion, and forage fish and zooplankton from central California. Mar. Pollut. Bull. 36: 828-832.

Szteren D, Aurioles-Gamboa D. 2011. Ecological regionalization of Zalophus californianus rookeries, as a tool for conservation in the Gulf of California. Cienc. Mar. 37: 349-368. http://dx.doi.org/10.7773/cm.v37i3.1818

Szteren D, Aurioles-Gamboa D, Gerber LR. 2006. Population status and trends of the California Sea lion in the Gulf of California, Mexico. In: Trites A, Atkinson S, DeMaster D, Fritz L, Gelatt T, Rea L, Wynne K (eds), Sea Lions of the World. Alaska Sea Grant College Program, Fairbanks, Alaska, pp. 369-384.

Thompson DR. 1990. Metal levels in marine vertebrates. In: Furness RW, Rainbow PS (eds.), Heavy Metals in the Marine Environment. CRC Press, Boca Raton, Florida, pp. 143-182.

Triffitt JT. 1985. Receptor molecules, coprecipitation and ion exchange process in the deposition of metal ions in bone. In: Priest ND (ed.), Metals in Bone Radiation Protection. Proceedings of a EU LEP symposium on the deposition, retention and effects of radioactive and stable metals in bone and marrow tissues. EULEP Symposium, 11-13 October 1984, Angers, France. MTP Press Limited, Lancaster, UK.

Ward EJ, Chirakkal H, González-Suárez M, Aurioles-Gamboa D, Holmes EE, Gerber LR. 2010. Inferring spatial structure from time-series data: Using multivariate state-space models to detect metapopulation structure of California sea lions in the Gulf of California, Mexico. J. Appl. Ecol. 47: 47-56. http://dx.doi.org/10.1111/j.1365-2664.2009.01745.x

Wren CD, Harris S, Hattruo N. 1995. Ecotoxicology of mercury and cadmium. In: Hoffman DJ, Rattner BA, Burton GA Jr, Cairns J $\mathrm{Jr}$ (eds.), Handbook of Ecotoxicology. Lewis Publishers, Boca Raton, Florida, pp. 392-423.

Received February 2013, received in revised form June 2013, accepted July 2013. 